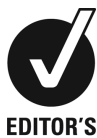

CHOICE

\title{
Extensive maxillofacial plasmablastic lymphoma in an immunocompetent patient
}

\author{
Zacharias Vourexakis, Pavel Dulguerov
}

Department of Otolaryngology, Head and Neck Surgery, Geneva University Hospital, Geneva, Switzerland

\section{Correspondence to} Dr Zacharias Vourexakis, zkvourexakis@yahoo.com

Accepted 20 July 2014

\section{DESCRIPTION}

A 46-year-old man presented to a dentist reporting maxillary pain on the left side which had persisted for a few weeks. The pain along with an irregular appearance of the gingival mucosa were attributed to dental pathology and a molar was extracted. The initially limited gingival lesion evolved into a rapidly growing palatal tumour and recurrent episodes of unilateral epistaxis occurred. A CT scan and a biopsy were performed and the patient was referred to our department several weeks after the first symptoms had appeared.

Inspection of the oral cavity revealed a purple, fleshy, well-delimited exophytic tumour occupying the entire hard palate on the left and deforming the maxillary gingiva (figure 1). The left nasal cavity was also filled with a solid mass. A CT scan and MRI confirmed the presence of a voluminous
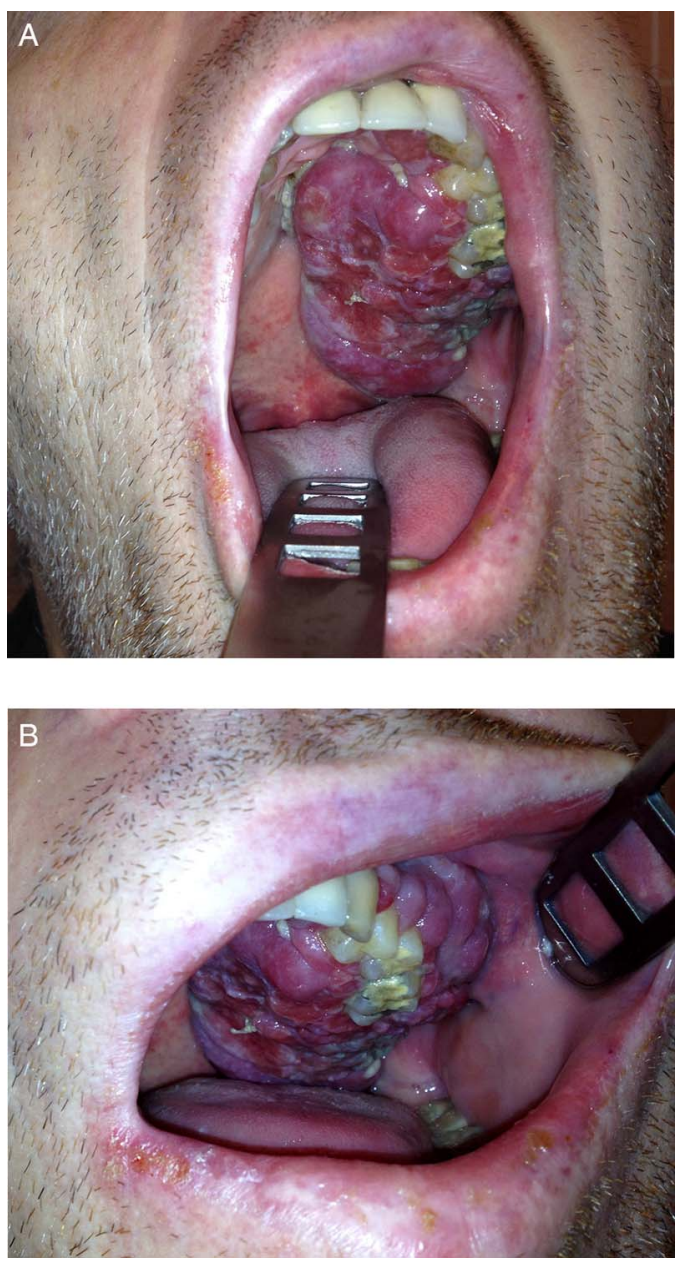

Figure 1 The tumour was well delimited, with an exophytic 'fleshy' appearance, occupying the hard palate (A) and extending to the maxillary gingiva (B) on the left side.

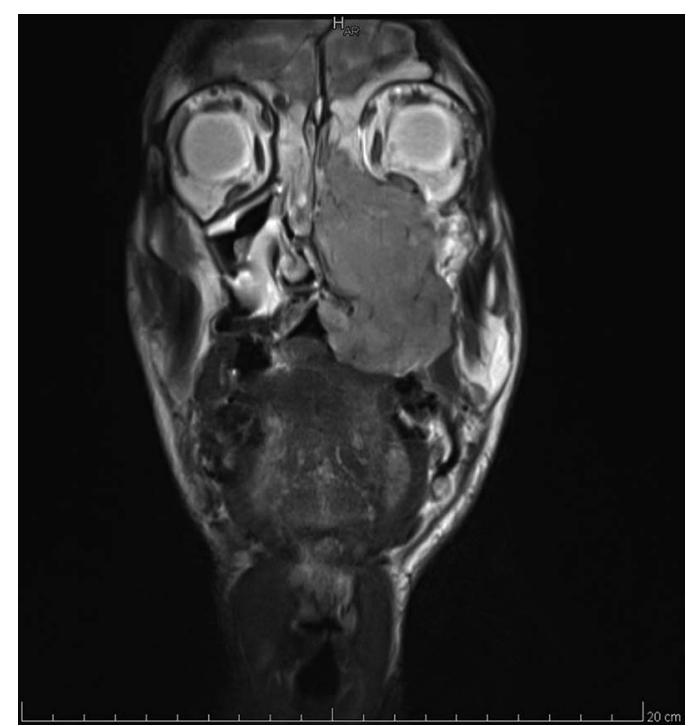

Figure 2 An MRI T2-weighted coronal view through the maxillary sinus, revealing a destructive tumour extending from the oral cavity to the ethmoid and the orbit through the maxilla and the nasal cavity.

tumour destroying the left maxilla and extending to the ethmoid, the orbit, the nasal cavity, the masticator space and the oral cavity (figure 2). A PET-CT scan revealed pulmonary and bone involvement along with multiple lymphadenopathies (cervical, mediastinal, subdiaphragmatic). Histology and immunohistochemistry (CD20-/+, CD79a-/+, VS38c+, CD10+, MUM1+, $\kappa-, \lambda-$, BCL2-, BCL6-, MiB1 90\%) confirmed the diagnosis of EBV+ plasmablastic lymphoma (PBL). Bone marrow biopsy and HIV testing were negative. Despite aggressive chemotherapy the patient died 8 months later.

Lymphomas are rare among sinonasal, maxillary and palatal tumours, the differential diagnosis including both malignant and benign lesions (such as squamous cell carcinoma, accessory salivary gland tumours, adenocarcinoma, sarcomas, odontogenic tumours). PBL was first described by Delecluse et al in 1997. ${ }^{1}$ It is a rare and aggressive B-cell lymphoma, usually associated with EpsteinBarr virus (EBV) infection and mainly occurring in immunodeficient, most often HIV-infected, patients $^{2}$; the oral cavity is a common location although extraoral forms exist and have a worse prognosis. Treatment is not standardised; it is generally based on multiagent chemotherapy with or without radiation therapy and stem cell transplantation. The overall prognosis remains poor with 1 -year survival of less than $50 \% .^{2}$ 


\section{Learning points}

- Patients reporting unilateral nasal symptoms (epistaxis, new-onset discharge and progressive obstruction), unexplained maxillary pain or hypoaesthesia should be referred to an otolaryngologist for nasal endoscopy.

- In most cases, biopsies of suspect lesions of the oral and nasal cavity are easy to perform, even on an outpatient basis; being essential for accurate diagnosis and an appropriate treatment, it is important to realise them in a timely fashion.

- Plasmablastic lymphoma is a rare B-cell lymphoma with poor prognosis, most frequently occurring in the oral cavity and mainly affecting immunocompromised patients.
Contributors Both authors have contributed to the treatment of the patient and the writing of this manuscript.

Competing interests None.

Patient consent Not obtained.

Provenance and peer review Not commissioned; externally peer reviewed.

\section{REFERENCES}

1 Delecluse HJ, Anagnostopoulos I, Dallenbach F, et al. Plasmablastic lymphomas of the oral cavity: a new entity associated with the human immunodeficiency virus infection. Blood 1997;89:1413-20.

2 Hansra D, Montague N, Stefanovic A, et al. Oral and extraoral plasmablastic lymphoma: similarities and differences in clinicopathologic characteristics. Am I Clin Pathol 2010;134:710-19.

Copyright 2014 BMJ Publishing Group. All rights reserved. For permission to reuse any of this content visit http://group.bmj.com/group/rights-licensing/permissions.

BMJ Case Report Fellows may re-use this article for personal use and teaching without any further permission.

Become a Fellow of BMJ Case Reports today and you can:

- Submit as many cases as you like

- Enjoy fast sympathetic peer review and rapid publication of accepted articles

- Access all the published articles

- Re-use any of the published material for personal use and teaching without further permission

For information on Institutional Fellowships contact consortiasales@bmjgroup.com

Visit casereports.bmj.com for more articles like this and to become a Fellow 